\title{
A Note on Conventions in the Text, Tables, and Maps
}

\section{PLACE NAMES}

The conventions for place names used in this book are largely pinyinized versions of those in G. William Skinner, Modern Chinese Society: An Analytical Bibliography (Stanford: Stanford University Press, 1973).

The generic designation xian (county) is omitted except where the name would otherwise have only one syllable. Conversely, two-syllable place names with no generic designation are xian.

For higher-level administrative units and one-syllable xian, a distinction is made between the administrative unit and the settlement that was the capital of that unit. In the former case, the generic designation is given as a separate word; for example, "Wei xian" refers to the county Wei xian in Shandong, and "Guangzhou fu," to the prefecture of Guangzhou fu in Guangdong. In the latter case, the generic part of the name is hyphenated, and thus "Wei-xian" and "Guangzhou-fu" denote the capitals of the two units mentioned above.

\section{TABLES}

The following conventions are used in Tables 2.I, 2.2, 6.I, 8.I, and 9.I:

Names are as of 1893; names in 1940, where different, are given in parentheses.

Where a county name appears in parentheses, the parentheses indicate that although data exist for that administrative unit, it was not established as a countylevel unit in 1820 (the base date for the maps).

All units were xian in 1940; units that were not xian in 1893 are specified.

Province is specified following the name of the county unit. 
Macroregions

$\begin{array}{ll}\text { GY } & \text { Gan Yangzi } \\ \text { LN } & \text { Lingnan } \\ \text { LY } & \text { Lower Yangzi } \\ \text { MY } & \text { Middle Yangzi }\end{array}$

$\begin{array}{ll}\text { N } & \text { North China } \\ \text { NW } & \text { Northwest China } \\ \text { SEC } & \text { Southeast Coast } \\ \text { UY } & \text { Upper Yangzi }\end{array}$

Provinces

$\begin{array}{llll}\text { AN } & \text { Anhui } & \text { HN } & \text { Hunan } \\ \text { FJ } & \text { Fujian } & \text { JS } & \text { Jiangsu } \\ \text { GD } & \text { Guangdong } & \text { JX } & \text { Jiangxi } \\ \text { GS } & \text { Gansu } & \text { SA } & \text { Shaanxi } \\ \text { GX } & \text { Guangxi } & \text { SC } & \text { Sichuan } \\ \text { HB } & \text { Hubei } & \text { ZJ } & \text { Zhejiang }\end{array}$

Time of Migration

$\begin{array}{llll}\text { SZ } & \text { Shunzhi, I644-62 } & \text { DG } & \text { Daoguang, I82I-51 } \\ \text { KX } & \text { Kangxi, I662-1723 } & \text { XF } & \text { Xianfeng, I85I-62 } \\ \text { YZ } & \text { Yongzheng, I723-36 } & \text { TZ } & \text { Tongzhi, I862-75 } \\ \text { QL } & \text { Qianlong, I736-96 } & \text { GX } & \text { Guangxu, I875-1908 }\end{array}$

JQ Jiaqing, $1796-1821$

\section{References to Sources}

\begin{tabular}{|c|c|c|c|}
\hline Cao (I) & $\begin{array}{l}\text { Cao Shuji, "Ming-Qing shiqi } \\
\text { de liumin he Gan-nan shanqu } \\
\text { de kaifa" }\end{array}$ & $\begin{array}{l}\mathrm{TZ} \\
\mathrm{XCZ} \\
\mathrm{XIZY}\end{array}$ & $\begin{array}{l}\text { ting zhi } \\
\text { xian ci zhi } \\
\text { Xiiiang zhengrao }\end{array}$ \\
\hline Cao (2) & Cao Shuji, "Ming-Qing shiqi & XTZ & xiangtu zhi \\
\hline & de liumin he Gan- & $\mathrm{XXZ}$ & xian xu zhi \\
\hline & bei shanqu de kaifa" & $\mathrm{XZ}$ & xian zhi (of the relevant \\
\hline Chen & & & county unless otherwise \\
\hline Yundor & Chen Yundong, Taiwan de & & specified) \\
\hline & kejiaren & ZPYZ & Zhupi yizhi \\
\hline FZ & fu zhi & $\mathrm{ZZ}$ & zhou zhi (of the relevant de- \\
\hline SZ & shi zhi & & $\begin{array}{l}\text { partment unless otherwise } \\
\text { specified) }\end{array}$ \\
\hline
\end{tabular}

Entries citing Cao (I) and Cao (2) as sources have been added by the editor. Although the two works by Cao are secondary sources, they are fully referenced, and primary sources can be ascertained by consulting them.

These abbreviations are also used in the Notes. 
MAPS (CONTRIBUTED BY G. WILLIAM SKINNER)

All maps for this volume were designed to depict administrative arrangements and hydrology as of 1820 . Beginning with a large-scale computerized map of modern China and using GIS (geographic information systems) technology, we modified the coastline and river systems as necessary to reflect the situation in the early nineteenth century, and we plotted administrative capitals and prefectural boundaries as they were at the end of the Jiaqing reign. Our source for constructing the 1820 base map was Zhongguo lishi dituji (The historical atlas of China), produced under the general editorship of Professor Tan Qixiang (Beijing: Ditu chubanshe, 1987). The language data shown in Maps 2.3 and 6.2 were adapted from the Language Atlas of China (Hong Kong: Longman, 1987).

Caveats and technical comments for particular maps accompany their presentation in the text. 

Migration and Ethnicity in Chinese History 
